\title{
Pengaruh Perilaku Belajar terhadap Tingkat Pemahaman Akuntansi dengan Kecerdasan Emosional sebagai Variabel Pemoderasi
}

\author{
Anak Agung Ngurah Agung Kresnandra \\ Fakultas Ekonomi dan Bisnis \\ Universitas Udayana, Indonesia. \\ Email: ngurahagungkresnandra@unud.ac.id
}

\begin{abstract}
ABSTRAK
Tujuan penelitian ini adalah untuk mengetahui pengaruh masing-masing variabel perilaku belajar dan kecerdasan emosional pada tingkat pemahaman akuntansi, serta pengaruh moderasi kecerdasan emosional pada interaksi perilaku belajar, pada tingkat pemahaman akuntansi. Pemilihan sampel menggunakan purposive sampling sebanyak 87 sampel. Data tingkat pemahaman akuntansi yang diproksikan dengan ratarata nilai akhir mata kuliah pokok akuntansi di program MAKSI dikumpulkan dari program SIMAK Unud, sedangkan data perilaku belajar dan kecerdasan emosional merupakan data respon yang dikumpulkan dengan menggunakan kuisioner yang telah memenuhi uji validitas dan realibilitas. Keseluruhan data telah memenuhi uji asumsi klasik dan model regresi telah memenuhi uji kelayakan model. Hasil uji regresi menunjukkan bahwa masing-masing variabel perilaku belajar dan kecerdasan emosional berpengaruh positif dan signifikan pada tingkat pemahaman akuntansi, selain itu kecerdasan emosional memoderasi pengaruh perilaku belajar pada tingkat pemahaman akuntansi.
\end{abstract}

Kata Kunci :

Kecerdasan emosional, perilaku belajar, tingkat pemahaman akuntansi.

\section{The Effect of Learning Behavior of Accounting Understanding with Emotional Intelligence as A Moderating Variable}

\begin{abstract}
ABSTRAC
The purpose of this study was to determine the effect of each variable of learning behavior and emotional quotient at accounting understanding level, and the influence of emotional quotient moderation on the interaction of learning behavior, at accounting understanding level. Sample selection using purposive sampling for 87 samples. Accounting understanding level data is proxied by the average final grade of accounting subjects in the MAKSI program collected from the SIMAK Unud program, while learning behavior and emotional quotient data are response data collected using questionnaires that have met the validity and reliability tests. All data have met the classical assumption test and the regression model has fulfilled the model feasibility test. Regression test results show that each variable of learning behavior and emotional quotiente has a positive and significant effect on the level of accounting understanding, besides that emotional quotiente increases the influence of learning behavior on accounting understanding level.
\end{abstract}

Keywords :

Accounting understanding level, emotional quotient, learning behavior.

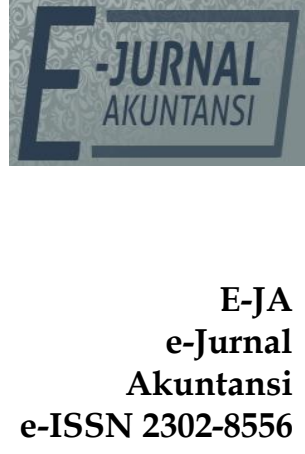

Vol. 28 No. 3

September 2019

Hal. 2065-2075

Artikel masuk:

28 Agustus 2019

Tanggal diterima: 11 September 2019 


\section{PENDAHULUAN}

Sesungguhnya, profesi akuntansi telah dibekali pengetahuan etika ketika mengikuti perkuliahan S1 maupun pendidikan profesi akuntansi. Namun kenyataannya, seperti diuraikan sebelumnya, tidak sedikit kasus merebak yang mengaitkan rendahnya integritas profesi akuntansi dalam memegang teguh kode etik dan etika profesinya. Sangat patut diduga hal ini terjadi, salah satunya, karena konten mata kuliah etika dan profesi yang diberikan kepada mahasiswa masih parsial yaitu hanya mengedepankan aspek perilaku belajar saja, dan kurang mengakomodasi kecerdasan emosional.

Penelitian ini dimotivasi oleh fakta bahwa sampai saat ini pendidikan akuntansi belum menginkulturasi nilai kecerdasan emosional kedalam kurikulum pendidikannya padahal banyak pakar dan hasil riset menunjukkan peran signifikan dari kecerdasan tersebut dalam meningkatkan tingkat pemahaman pengetahuan. Sehingga melalui penelitian ini akan diperoleh bukti empiris yang akan menjadi tambahan acuan bagi pengambilan kebijakan pendidikan akuntansi.

Penelitian ini berbeda dengan Rachmi (2010) yang ingin mengetahui hanya pengaruh masing-masing variabel perilaku belajar, kecerdasan emosional, dan kecerdasan spiritual pada tingkat pemaham akuntansi, sedangkan penelitian ini juga ingin mengetahui peran moderasi kecerdasan emosional pada tingkat pemahaman akuntansi. Riset Mulawarman dan Ludigdo (2010), mencoba mengetahui pengaruh ketiga oleh "trio" kecerdasan (IQ, EQ dan SQ), penelitian ingin mengetahui peran "duo" kecerdasan (emosional dan spiritual) dalam meningkatkan pengaruh perilaku belajar pada tingkat pemahaman akuntansi dan sikap etis.

Suwardjono (1992) menyatakan bahwa ada enam aspek dalam belajar di sebuah perguruan tinggi, antara lain: makna kuliah, pengalaman belajar atau nilai, konsepsi dosen, kemandirian sdalam belajar, kemampuan berbahasa dan konsep memiliki buku. Pengukuran prestasi akademik merupakan aspek yang sangat penting untuk mengetahui tingkat keberhasilan yang dicapai mahasiswa dalam belajar. Winkel (1984) menyatakan bahwa, prestasi adalah bukti keberhasilan usaha yang tercapai. Jadi, jika prestasi akademik seorang mahasiswa itu baik, maka dapat dikatakan jika mahasiswa tersebut telah memperoleh hasil yang baik dari serangkaian proses belajar yang selama ini ditempuhnya. Dengan perilaku belajar yang baik berarti banyak waktu dan konsentrasi yang diberikan oleh mahasiswa untuk menggali dan menghimpun pengetahuan akuntansi termasuk di dalamnya perihal sikap etis dan perilaku etis profesi akuntan. Hasil riset terdahulu seperti yang dilakukan oleh Nugraha (2013), Rokhana dan Sutrisno (2016) , Aulia (2016), serta Wardani dan Ratnadi (2017), menemukan hasil bahwa perilaku belajar memiliki pengaruh yang positif terhadap tingkat pemahaman akuntansi. Dari uraian rerangka pemikiran tersebut dapat dikembangkan hipotesis sebagai berikut:

$\mathrm{H}_{1}$ : Perilaku belajar berpengaruh pada tingkat pemahaman akuntansi.

Kecerdasan emosional (EQ) menentukan seberapa baik seseorang menggunakan keterampilan-keterampilan yang dimilikinya, termasuk keterampilan intelektual. Kesulitan belajar yang dicirikan oleh menurunnya prestasi belajar sebagai bentuk kegagalan bisa berkaitan dengan dominan afektif, misalnya situasi emosi akan mempengaruhi belajar Winkel dalam (Nugraheni 
2008). Salovey dan Mayer (1996) mendefinisikan kecerdasan emosional sebagai himpunan bagian dari kecerdasan sosial yang melibatkan kemampuan "memantau perasaan dan emosi", baik pada diri sendiri maupun pada orang lain, memilah-milah dan menggunakan informasi itu untuk membimbing pikiran dan tindakan. Kualitas-kualitas EQ ini antara lain; empati, mengungkapkan dan memahami perasaan, mengendalikan amarah, kemandirian, kemampuan menyesuaikan diri, disukai, kemampuan memecahkan masalah antarpribadi, ketekunan, kesetiakawanan, keramahan dan sikap hormat. Semua kualitas di ataslah yang lebih banyak berperan dalam kehidupan seseorang untuk meraih sukses.

$\mathrm{H}_{2}$ : Kecerdasan emosional berpengaruh pada tingkat pemahaman akuntansi.

Secara kuantitatif IQ hanya menyumbangkan kira-kira 20 persen bagi faktor-faktor yang menentukan keberhasilan seseorang, sedangkan 80 persen diisi oleh kekuatan-kekuatan lain (EQ) (Goleman, (2003:44). Hasil riset yang dilakukan oleh Nugraha (2013), Rokhana dan Sutrisno (2016), serta Wardani dan Ratnadi (2017), menemukan hasil bahwa kecerdasan emosional (EQ) memiliki pengaruh positif dan signifikan terhadap tingak pemahaman akuntansi. Berdasarkan kerangka pemikiran di atas, dapat disusun hipotesis sebagai berikut:

$\mathrm{H}_{3}$ : Kecerdasan emosional berperan meningkatkan pengaruh perilaku belajar pada tingkat pemahaman akuntansi.

\section{METODE PENELITIAN}

Berdasarkan rumusan hipotesis yang telah dikembangkan sebelumnya maka dapat dibuat desain peneitian seperti terlihat pada gambar berikut ini:

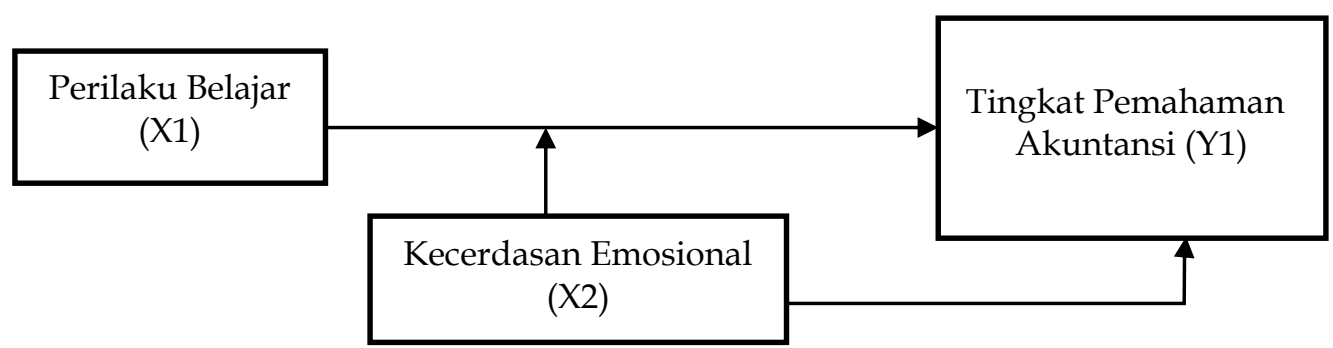

Gambar 1. Desain Penelitian

Sumber: Data Penelitian, 2018

Penelitian ini dilakukan di Program Magister Akuntansi (MAKSI) Program Pasca Sarjana Fakultas Ekonomi dan Bisnis (FEB) Unud. Objek penelitian yang digunakan dalam penelitian ini adalah tingkat pemahaman akuntansi mahasiswa. Jenis data yang digunakan dalam penelitian ini adalah data kuantitatif untuk data tingkat pemahaman akuntansi dengan sumber data sekunder yang dikumpulkan dengan metode dokumentasi atau obervasi non-perilaku. Jenis data yang lain adalah data respon yang dikuantifikasi untuk data perilaku belajar dan kecerdasan emosional, yang dikumpulkan dari sumber data primer dengan menggunakan kuisioner.

Populasi dalam penelitian ini meliputi mahasiswa akuntansi dan mata kuliah Akuntansi di program MAKSI FEB Unud. Dari seluruh jumlah mahasiswa akuntansi tersebut diambil sampel dengan menggunakan metode purposive 
sampling. Purposive sampling (pemilihan sampel bertujuan) digunakan dalam pemilihan sampel secara tidak acak dengan kriteria mahasiswa tersebut telah menempuh mata kuliah pokok Akuntansi sehingga dapat dianggap telah mendapat manfaat yang maksimal dari mata kuliah yang bermuatan akuntansi dan memiliki diversifikasi tujuan, cita-cita dan impian hidup, berpikir rasional sebelum bertindak yang semuanya dapat dihubungkan dengan muatan akuntansinya.

Variabel Perilaku Belajar (X1) diukur dari empat dimensi yang berhubungan erat dengan perilaku belajar yaitu: kebiasaan mengikuti pelajaran, kebiasaan memantapkan pelajaran, kebiasaan membaca buku, Kebiasaan menyiapkan karya tulis, kebiasaan menghadapi ujian (Suwardjono, 1991). Melandry dkk (2007), dalam Hariyoga \& Suprianto (2011), menyatakan bahwa , variabel kecerdasan emosional diukur dengan lima dimensi atau komponen kecerdasan emosional (EQ) (X2) yang keseluruhannya diturunkan menjadi dua puluh lima kompetensi ini yang dimodifikasi menjadi lima belas kompetensi. Kelima dimensi atau komponen tersebut adalah sebagai berikut: Pengenalan Diri, Pengendalian Diri, Motivasi Diri, Empati, dan Kemampuan Sosial.

Variabel tingkat pemahaman akuntansi diukur dengan point of view tingkat pemahaman akuntansi adalah nilai rata-rata mata kuliah pokok Akuntansi di program MAKSI adalah mata kuliah Teori Akuntansi Akuntansi Manajemen Sistem Informasi Akuntansi Seminar Auditing Seminar Akuntansi Keuangan Analisis Laporan Keuangan Akuntansi Keperilakuan.

Teknik analisis data dalam penelitian ini menggunakan Moderating Regression Analysis (MRA). Formula yang digunakan menurut (Sugiyono, 2014:62) adalah sebagai berikut:

$Y=\alpha+\beta_{1} X_{1}+\beta_{2} X_{2}+\beta_{3} X_{1} . X_{2}+e$

Keterangan :

$$
\begin{array}{ll}
\mathrm{Y}_{\mathrm{i}} & =\text { Tingkat Pemahaman Akuntansi }(\mathrm{Y}) \\
\mathrm{a} & =\text { Konstanta } \\
\beta_{1} \ldots \beta_{3} & =\text { Koefisien Beta } \\
\mathrm{X}_{1} & =\text { Perilaku Belajar } \\
\mathrm{X}_{2} & =\text { Kecerdasan Emosional } \\
\mathrm{X}_{1} \cdot \mathrm{X}_{2} & =\text { interaksi Perilaku Belajar dan Kecerdasan Emosional } \\
\mathrm{e} & =\text { error }
\end{array}
$$

Sebelum dilakukan pengujian hipotesis, data terlebih dahulu diuji asumsi klasik. Hal ini dilakukan untuk menghindari terjadinya bias dalam estimasi, mengingat tidak semua data dapat diterapkan regresi. Pengujian asumsi klasik meliputi uji normalitas, uji heteroskedastisitas dan uji multikolinearitas.

\section{HASIL DAN PEMBAHASAN}

Uji validitas dimaksudkan untuk menguji valid atau tidak validnya suatu kuesioner. Suatu kuesioner dapat dikatakan valid jika pertanyaan pada kuesioner mampu untuk mengungkapkan sesuatu yang akan diukur oleh kuesioner tersebut. Pada penelitian kali ini untuk mengukur validitas digunakan uji korelasi bivariate antara masing-masing skor indikator dengan total skor konstruk. Dari hasil perhitungan SPSS diperoleh hasil validitas dari masing-masing variabel adalah sebagai berikut: 
Hasil uji validitas variabel perilaku belajar $\left(X_{1}\right)$ dapat dilihat pada Table 1. Tabel 1. Hasil Uji Validitas Instrumen Variabel Perilaku Belajar

\begin{tabular}{cccc}
\hline Indikator & $r_{\text {hitung }}$ & rabel & Validitas \\
\hline PB1 & 0,662 & 0,3 & Valid \\
PB2 & 0,511 & 0,3 & Valid \\
PB3 & 0,488 & 0,3 & Valid \\
PB4 & 0,692 & 0,3 & Valid \\
PB5 & 0,566 & 0,3 & Valid \\
PB6 & 0,684 & 0,3 & Valid \\
PB7 & 0,552 & 0,3 & Valid \\
PB8 & 0,693 & 0,3 & Valid \\
PB9 & 0,401 & 0,3 & Valid \\
PB10 & 0,591 & 0,3 & Valid \\
PB11 & 0,551 & 0,3 & Valid \\
PB12 & 0,491 & 0,3 & Valid \\
PB13 & 0,541 & 0,3 & Valid \\
\hline
\end{tabular}

Sumber: Data Penelitian, 2018

Berdasarkan Tabel 1 dapat diketahui bahwa semua item pada variabel perilaku belajar mempunyai koefisiem korelasi $>0,3$ sehingga dapat dikatakan bahwa semua pertanyaan valid atau lolos uji validitas. Hasil uji validitas variabel kecerdasan emosional $\left(\mathrm{X}_{2}\right)$ dapat dilihat pada Tabel 2.

Tabel 2. Hasil Uji Validitas Instrumen Variabel Kecerdasan Emosional $\left(X_{2}\right)$

\begin{tabular}{lccc}
\hline Indikator & $\mathrm{r}_{\text {hitung }}$ & $\mathrm{r}_{\text {tabel }}$ & Validitas \\
\hline EQ1 & 0,355 & 0,3 & Valid \\
EQ2 & 0,513 & 0,3 & Valid \\
EQ3 & 0,393 & 0,3 & Valid \\
EQ4 & 0,327 & 0,3 & Valid \\
EQ5 & 0,455 & 0,3 & Valid \\
EQ6 & 0,524 & 0,3 & Valid \\
EQ7 & 0,574 & 0,3 & Valid \\
EQ8 & 0,457 & 0,3 & Valid \\
EQ9 & 0,642 & 0,3 & Valid \\
EQ10 & 0,554 & 0,3 & Valid \\
EQ11 & 0,552 & 0,3 & Valid \\
EQ12 & 0,34 & 0,3 & Valid \\
EQ13 & 0,37 & 0,3 & Valid \\
EQ14 & 0,561 & 0,3 & Valid \\
EQ15 & 0,46 & 0,3 & Valid \\
\hline
\end{tabular}

Sumber: Data Penelitian, 2018 
Berdasarkan Tabel 2, dapat diketahui bahwa semua item pada variabel kecerdasan emosional mempunyai koefisien korelasi $>0,3$ sehingga dapat dikatakan semua item pertanyaan dinyatakan valid atau lolos uji validitas. Uji reliabilitas instrumen dalam penelitian ini dapat dilihat pada Tabel 3.

Tabel 3. Hasil Uji Reliabilitas Instrumen Variabel $X_{1}, X_{2}$ dan $Y$

\begin{tabular}{|c|c|c|c|}
\hline Aspek Variabel & Cronbach's Alpha & Nilai kritis/ Standard & Reliabilitas \\
\hline $\begin{array}{l}\text { Perilaku } \\
\text { (X1) }\end{array}$ & 0,789 & $>0,6$ & Reliabel \\
\hline $\begin{array}{l}\text { Kecerdasan emosi } \\
\text { (X2) }\end{array}$ & 0,794 & $>0,6$ & Reliabel \\
\hline Sikap Etis (Y) & 0,753 & $>0,6$ & Reliabel \\
\hline
\end{tabular}

Sumber: Data Penelitian, 2018

Berdasarkan ringkasan hasil uji reliabilitas seperti disajikan dalam Tabel 3, dapat diketahui bahwa nilai koefisien Cronbach Alpha pada variabel ini nilainya lebih besar dari 0,6 sehingga dapat disimpulkan bahwa semua butir pertanyaan terkait variabel penelitian ini, berdasarkan kriteria Nunally dalam Ghozali (2005), adalah reliabel.

Uji asumsi klasik dalam penelitian ini yaitu uji normalitas, multikolinearitas dan heteroskedastisitas. Uji normalitas memiliki tujuan untuk menguji keberadaan variable pengganggu dalam model regresi atau residual memiliki distribusi normal. Untuk menguji normalitas dalam penelitian ini peneliti menggunakan uji statistik dengan parametrik Kolmogrorov-Smirnow test yang disajikan pada Tabel 4 .

Tabel 4. Hasil Uji Normalitas

\begin{tabular}{llr}
\hline & & Unstandardized Residual \\
\hline $\mathrm{N}$ & & 87 \\
Normal Parameters(a,b) & Mean & .0000000 \\
& Std. Deviation & 1.66853958 \\
Most Extreme Differences & Absolute & .121 \\
& Positive & .121 \\
& Negative & -.108 \\
Kolmogorov-Smirnov Z & & 1.132 \\
Asymp. Sig. (2-tailed) & & .154 \\
\hline
\end{tabular}

Sumber: Data Penelitian, 2018

Berdasarkan tabel 4 dapat diketahui menunjukan bahwa nilai Sig. (2tailed) dalam One-Sample Kolmogorov-Smirnov Test adalah 0,154 yang lebih besar dari $>0,05$, sehingga $\mathrm{H}_{0}$ diterima. Ini berarti bahwa data yang diuji menyebar normal/terdistribusi normal.

Uji multikolinearitas dilakukan untuk mengetahui ada atau tidaknya gejala multikolinearitas pada model regresi yang dibuat dilihat berdasarkan matriks korelasi antar variabel independen. Hasil pengujian multikolinearitas dapat dilihat pada tabel 5 .

Tabel 5. Hasil Uji Multikolinearitas

\begin{tabular}{lll}
\hline Variabel & Tolerance & VIF \\
\hline Perilaku Belajar & 0,673 & 1,485 \\
Kecerdasan Emosional & 0,727 & 1,376 \\
\hline
\end{tabular}

Sumber: Data Penelitian, 2018 
Berdasarkan hasil uji multikolinearitas pada Tabel 5 dapat diketahui bahwa semua variabel independen memiliki tolerance lebih besar dari 10 persen $(0,1)$ dan VIF kurang dari 10, sehingga tidak ada indikasi terjadinya gejala multikolinearitas.

Hasil uji heteroskedastisitas dapat dilihat pada Tabel 6, yang dapat ditarik kesimpulan tidak ada satupun variabel independen yang signifikan secara statistik mempengaruhi variabel dependen karena nilai $p$-value berada di atas 0,05. Tabel 6. Hasil Uji Heterokedastisitas dengan Glejser

\begin{tabular}{lcl}
\multicolumn{1}{c}{ Variabel } & Signifikansi & Keterangan \\
\hline $\begin{array}{l}\text { Perilaku Belajar }(\mathrm{X} 1) \\
\begin{array}{l}\text { Kecerdasan Emosi } \\
(\mathrm{X} 2)\end{array}\end{array}$ & 0,668 & Bebas heteroskedastisitas \\
\hline
\end{tabular}

Sumber: Data Penelitian, 2018

Dari 87 amatan yang telah lolos uji asumsi klasik diperoleh nilai deskripsi statistik tentang nilai minimum, nilai maksimum dan nilai rata-rata dari data penelitian, yang disajikan dalam table 7 .

Tabel 7. Hasil Deskriptif Statistik

\begin{tabular}{lccc}
\hline \multicolumn{1}{c}{ Variabel } & Min. & Max. & Mean \\
\hline Perilaku Belajar & 24.00 & 45.00 & 37.0115 \\
Kecerdasan Emosi & 60.00 & 106.00 & 87.5402 \\
Tingkat Pemahaman Akuntansi & 14.00 & 20.00 & 17.0000 \\
\hline
\end{tabular}

Sumber: Data Penelitian, 2018

Berdasarkan ini dapat diketahui rata-rata respon responden atas variabel perilaku belajar, kecerdasan emosional dan pemahaman akuntansi masingmasing 37,01; 87,54 dan 17,00.

Pengujian Kelayakan Model (Uji F) untuk mengetahui seberapa layak sebuah model regresi digunakan sebagai alat analisis untuk menguji pengaruh variabel independen terhadap variabel dependennya. Hasil uji kelayakan model disajikan pada Tabel 8 untuk persamaan regresi berganda dengan variabel dependen tingkat pemahaman akuntansi.

Tabel 8. Hasil Uji Kelayakan Model (Uji F)

\begin{tabular}{ccc}
\hline R Square Change & F Change & Sig. F Change \\
\hline 0,239 & 3,663 & 0,000 \\
\hline
\end{tabular}

Sumber: Data Penelitian, 2018

Berdasarkan Tabel 8 dapat diketahui bahwa model regresi memiliki Pvalue (Sig. F Change) sebesar 0,000, nilai tersebut lebih kecil daripada a (5\%) sehingga dapat dikatakan bahwa model regresi tersebut memenuhi uji kelayakan model/model fit test.

Besarnya koefisien determinasi $\mathrm{R}^{2}$ masing-masing model regresi (2) dapat dilihat pada tabel 9 untuk persamaan regresi berganda dengan variabel dependen tingkat pemahaman akuntansi.

Tabel 9. Hasil Uji Koefisien Determinasi

\begin{tabular}{ccrrr}
\hline Model & $R$ & $R$ Square & $\begin{array}{l}\text { Adjusted } \\
R \text { Square }\end{array}$ & $\begin{array}{c}\text { Std. Error of the } \\
\text { Estimate }\end{array}$ \\
\hline 1 & $0,635(\mathrm{a})$ & 0,403 & 0,400 & 1,67929 \\
\hline
\end{tabular}

Sumber: Data Penelitian, 2018 
Berdasarkan tabel 9 dapat diketahui koefisien determinasi $\mathrm{R}^{2}$ adalah sebesar 40,3\% yang mengandung makna bahwa variasi perubahan variabel independen dalam model (perilaku belajar, kecerdasan emosional, dan kecerdasan spiritual) mampu menjelaskan variasi perubahan variabel dependen tingkat pemahaman akuntansi sebesar 40,3\% sedangkan sisanya sebesar 59,7\% dijelaskan oleh variasi perubahan variabel independen di luar model.

Hasil Moderated Regression Analysis (MRA) yang dilakukan dengan bantuan Program SPSS ver 19 for windows atas pengaruh variabel perilaku belajar pada tingkat pemahaman akuntansi dengan kecerdasan emosional dan kecerdasan spiritual sebagai pemoderasi dapat dilihat pada tabel 10 untuk variabel dependen tingkat pemahaman akuntansi sebagai berikut

Tabel 10. Hasil Uji Hipotesis dengan MRA

\begin{tabular}{lcccc}
\hline Variabel & \multicolumn{2}{c}{$\begin{array}{c}\text { Unstandardized } \\
\text { Coefficients }\end{array}$} & $\begin{array}{c}\text { Standardized } \\
\text { Coefficients }\end{array}$ & \multirow{2}{*}{ Sig. } \\
\cline { 2 - 4 } & $\mathrm{B}$ & $\begin{array}{c}\text { Std. } \\
\text { Error }\end{array}$ & Beta & \\
\hline (Constant) & 17,046 & 2,018 & & 0,000 \\
PB & 0,364 & 0,039 & 0,256 & 0,038 \\
KE & 0,256 & 0,021 & 0,234 & 0,029 \\
PB_KE & 0,986 & 0,020 & 0,245 & 0,033 \\
\hline
\end{tabular}

Sumber: Data Penelitian, 2018

Berdasarkan tabel 10 diperoleh persamaan regresi sebagai berikut:

$$
\mathrm{PA}=17,046+0,364 \times \mathrm{PB}+0,256 \times \mathrm{KE}+0,629 \times \mathrm{PB} \_\mathrm{KE}+\mathrm{e}
$$

Keterangan:

PA $=$ Tingkat Pemahaman Akuntansi

$\mathrm{PB} \quad=$ Perilaku Belajar $(\mathrm{PB})$

$\mathrm{KE} \quad=$ Kecerdasan Emosional $(\mathrm{KE})$

$\mathrm{PB} \_\mathrm{KE} \quad=$ Interaksi Perilaku Belajar (PB) dan Kecerdasan Emosional (KE)

$\mathrm{e}=$ error

Uji statistik $\mathrm{t}$ pada dasarnya dilakukan untuk menunjukkan seberapa jauh pengaruh satu variabel independen dan variabel moderasi secara individual dalam menerangkan variasi variabel dependen. Uji statistik $t$ dilakukan dengan membandingkan hasil nilai signifikansi $p$-value pengaruh variabel independen dan variabel interaksi terhadap masing-masing variabel dependen (tingkat pemahaman akuntansi dan sikap etis) dengan $\alpha=0,05$. Jika, p-value lebih kecil daripada $a=0,05$ maka variabel independen berpengaruh signifikan pada variabel dependen, dan sebaliknya, jika $p$-value lebih besar daripada $a=0,05$ maka variabel independen tidak berpengaruh signifikan pada variabel dependen.

Berdasarkan Tabel 10 diperoleh hasil uji regresi pengaruh parsial variabel independen PB pada tingkat pemahaman akuntansi (PA). Uji regresi variabel perilaku belajar (PB) pada tingkat pemahaman akuntansi (PA) diperoleh hasil koefisien $\beta=0,364$ dengan P-Value sebesar 0,038 yang lebih kecil daripada a (5\%). Ini berarti bahwa PB berpengaruh positif dan signifikan pada PA. Dengan demikian hasil uji hipotesis ini menerima hipotesis Ha.1 yang menyatakan bahwa perilaku belajar berpengaruh positif dan signifikan pada tingkat pemahaman akuntansi. Uji regresi pengaruh parsial perilaku belajar/PB pada tingkat pemahaman akuntansi/TPA pada penelitian ini diperoleh hasil bahwa PB 
berpengaruh positif dan signifikan pada TPA. Hasil ini sekaligus menguatkan hasil riset terdahulu oleh Rachmi (2010) yang menyatakan bahwa perilaku belajar memiliki pengaruh terhadap tingkat pemahaman mahasiswa terhadap materi kuliah. Selain Rachmi (2010), hasil riset ini juga mendukung beberapa hasil riset terdahulu oleh Nugraha (2013), Rokhana dan Sutrisno (2016) , Aulia (2016), serta Wardani dan Ratnadi (2017), yang seluruhnya menyatakan bahwa perilaku belajar berpengaruh positif terhadap tingkat pemahaman akuntansi.

Tingkat pemahaman akuntansi mahasiswa Program MAKSI FEB Unud dipengaruhi oleh perilaku belajar mahasiswa baik dalam kegiatan perkuliahan di kelas maupun di luar kelas. Mahasiswa Program MAKSI memiliki keinginan untuk memperdalam pengetahuan dan pemahaman akuntansinya dengan jalan pergi ke ruang baca untuk membaca buku-buku referensi terkait, membuat forumforum diskusi sesama mahasiswa Program MAKSI, hingga berkonsultasi atau bertanya kepada dosen pengajar di luar jam perkuliahan jika ada materi yang kurang jelas. Hal-hal seperti ini merupakan perilaku belajar yang baik sehingga menyebabkan tingkat pemahaman akuntansi mahasiswa Program MAKSI FEB Unud meningkat.

Uji regresi variabel KE pada PA diperoleh hasil koefisien $\beta=0,256$ dengan P-Value sebesar 0,029 yang lebih kecil daripada a (5\%). Ini berarti bahwa KE berpengaruh positif dan signifikan pada PA. Dengan demikian hasil uji hipotesis ini menerima Ha.2 yang menyatakan bahwa kecerdasan emosional berpengaruh positif dan signifikan pada tingkat pemahaman akuntansi. Uji regresi pengaruh parsial kecerdasan emosional/KE pada tingkat pemahaman akuntansi/PA pada penelitian ini diperoleh hasil bahwa KE berpengaruh positif dan signifikan pada PA. Hasil penelitian ini konsisten dengan penelitian Efriyenti (2017) yang menyatakan bahwa kecerdasan emosional berpengaruh positif terhadap tingkat pemahaman akuntansi mahasiswa. Selain Efriyenti (2017), hasil riset ini juga mendukung hasil-hasil riset yang dilakukan oleh Nugraha (2013), Rokhana dan Sutrisno (2016) , serta Wardani dan Ratnadi (2017), yang menemukan hasil bahwa kecerdasan emosional (EQ) memiliki pengaruh positif dan signifikan terhadap tingak pemahaman akuntansi.

Tingkat pemahaman akuntansi mahasiswa Program MAKSI FEB Unud juga dipengaruhi oleh kecerdasan emosional. Hal ini juga mengindikasikan bahwa ilmu akuntansi tidak hanya didapatkan dari proses perkuliahan di kelas saja, selain itu materi dalam kuliah akuntansi terkadang tidak mencakup keseluruhan aspek dalam ilmu akuntansi, sehingga motivasi, keterampilan social dan hubungan dengan orang lain juga berpengaruh terhadap pemahaman terhadap akuntansi bagi mahasiswa Program MAKSI FEB Unud.

Uji interaksi moderasi PB dengan KE (PB_KE) pada PA diperoleh hasil koefisien $\beta=0,986$ dengan P-Value sebesar 0,033 yang lebih kecil daripada a (5\%). Ini berarti bahwa PB_KE berpengaruh positif dan signifikan pada PA. Dengan demikian hasil uji hipotesis ini menerima Ha.3 yang menyatakan bahwa kecerdasan emosional berperan meningkatkan pengaruh perilaku belajar pada tingkat pemahaman akuntansi. Uji regresi peran moderasi KE terhadap pengaruh PB pada PA dalam penelitian ini memperoleh hasil bahwa KE mampu memoderasi pengaruh PB pada PA. Dalam satu sisi, KE mampu memperkuat pengaruh positif PB pada PA. Hasil penelitian ini memberikan tambahan bukti 
empiris yaitu kemampuan individu untuk berperilaku atau bertindak secara tepat dan efektif sebagai bagian dari keberhasilan IQ akan lebih menjamin tingkat pemahaman yang baik jika disertai kemampuan pengendalian emosional. Hal ini sesuai dengan teori EQ oleh Goleman (2005), yang menekankan bahwa IQ yang diberi sentuhan EQ, meliputi sikap empati, mengendalikan amarah, mengungkapkan dan memahami perasaan, kemampuan menyesuaikan diri, kemandirian, disukai, kemampuan memecahkan masalah antar pribadi, kesetiakawanan, ketekunan, sikap hormat dan keramahan akan menjadi kekuatan seseorang untuk menyelesaikan masalah dengan pertimbangan aspek emosional;

\section{SIMPULAN}

Berdasarkan pembahasan yang telah dilakukan maka dapat disimpulkan yaitu, pertama perilaku belajar berpengaruh positif dan signifikan pada tingkat pemahaman akuntansi; kedua, kecerdasan emosional berpengaruh positif dan signifikan pada tingkat pemahaman akuntansi; ketiga, kecerdasan emosional meningkatkan pengaruh perilaku belajar pada tingkat pemahaman akuntansi.

Berdasarkan pembahasan telah dilakukan dan telaah atas pernyataan reponden maka dapat diajukan beberapa saran antara lain, pertama, pengelola Program Studi MAKSI perlu mempertimbangkan memasukkan materi keserdasan emosional ke dalam pengajaran etika bisnis dan profesi dan atau mewacanakan kedua kecerdasan ini dalam proses pembelajaran. Kedua, Ikatan Akuntan Indonesia sangat perlu memasukkan materi kecerdasan emosional dalam berbagai kegiatan Pendidikan dan Pelatihan Lanjutan (PPL) baik kegiatan kursus-kursus, sertifikasi, in-house training, dsb.

\section{REFERENSI}

Aulia, S. A. (2016). Pengaruh Pengendalian Diri, Motivasi, Dan Perilaku Belajar Terhadap Tingkat Pemahaman Akuntansi Mahasiswa. Economic Education Analysis Journal, 5(1), 346-362.

Efriyenti, D. (2017). Analisis Tingkat Pemahaman Mahasiswa Akuntansi Terhadap Konsep Dasar Akuntansi (Studi Empiris Pada Mahasiswa Akuntansi di Universitas Internasional Batam. Pekbis Jurnal, 9.

Goleman, D. (2003). EQ (13th ed.). Jakarta: PT Gramedia Pustaka Utama.

Goleman, D. (2005). Kecerdasan Emosi: Untuk Mencapai Puncak Prestasi. PT. Gramedia Pustaka Utama.

Hariyoga, S., \& Suprianto, E. (2011). Pengaruh Kecerdasan Emosional, Perilaku Belajar, Dan Budaya Terhadap Tingkat Pemahaman Akuntansi Dengan Kepercayaan Diri Sebagai Variabel Pemoderasi. Fakultas Ekonomi Universitas Syiah Kuala Banda Aceh, 21-22.

Mulawarman, A. D., \& Ludigdo, U. (2010). Metamorfosis Kesadaran Etis Holistik Mahasiswa Akuntansi Implementasi Pembelajaran Etika Bisnis dan Profesi Berbasis Integrasi IESQ. Jurnal Akuntansi Multiparadigma, 429-444. https://doi.org/10.18202/jamal.2010.12.7102

Nugraha, A. P. (2013). Pengaruh Kecerdasan Emosional dan Perilaku Belajar terhadap Tingkat Pemahaman Akuntansi (Studi pada Mahasiswa Akuntansi Universitas Jember). https:// doi.org/10.1017/CBO9781107415324.004

Nugraheni, D. W. I. W. (2008). Pengaruh Kecerdasan Emosional dan Lingkungan 
Belajar terhadap Pemahaman Akuntansi (Survei pada Mahasiswa Akuntansi di Perguruan Tinggi Se-Wilayah Eks Karesidenan Surakarta).

Rachmi, F. (2010). Pengaruh Kecerdasan Emosional, Kecerdasan Spiritual, dan Perilaku Belajar terhadap Tingkat Pemahaman Akuntansi (Studi Empiris pada Mahasiswa Akuntansi Universitas Diponegoro Semarang dan Universitas Gajah Mada Yogyakarta).

Rokhana, L. A., \& Sutrisno, S. (2016). Pengaruh Kecerdasan Emosional, Perilaku Belajar, Dan Minat Belajar Terhadap Tingkat Pemahaman Akuntansi. (Studi Empiris Pada Mahasiswa Akuntansi Fakultas Ekonomika Dan Bisnis UNTAG Semarang). 31(1), 26-38. https:// doi.org/10.24856/mem.v31i1.282

Salovey, P. \& Mayer, J. D. (1996). Emotional Intelligence and The Identification of Emotion. 22(2), 89-113.

Sugiyono. (2014). Metode penelitian pendidikan pendekatan kuantitatif.pdf. In Metode Penelitian Pendidikan Pendekatan Kuantitatif, Kualitatif Dan RED.

Suwardjono. (1991). Perilaku Belajar di Perguruan Tinggi. Jurnal Akuntansi STIE YKPN, (Maret).

Suwardjono. (1992). Gagasan Pengembangan Profesi dan Pendidikan Akuntansi di Indonesia (1st ed.). Yogyakarta: BPFE.

Wardani, N. W. R., \& Ratnadi, N. M. D. (2017). Pengaruh Kecerdasan Enosional, Kecerdasan Intelektual Dan Prilaku Belajar Pada Tingkat Pemahaman Akuntansi. Akuntansi Universitas Udayana Vol.20.2., 20(2), 1133-1161.

Winkel, W.S. (1984). Psikologi Pendidikan dan Evaluasi Belajar. PT Gramedia. 